\title{
(Nec) Plus Ultra: as epopeias antes e após as grandes navegações
}

\author{
(Nec) Plus Ultra: The Epics Before \\ and After the Great Navigations
}

Cleber Vinicius do Amaral Felipe*

\section{Resumo}

Até o século XVIII, os gêneros retóricos e poéticos foram regulados pela noção de imitação, ou seja, os poetas emulavam as autoridades (auctoritas) antigas para produzir seus escritos. Trata-se de um paradigma artístico que precedeu o Romantismo e que se amparou nas convenções e na especificidade de cada gênero discursivo. Embora devamos levar em consideração a longa duração da Instituição Retórica, não podemos negligenciar os aspectos históricos que amparam cada poema, ou seja, não é porque imitavam a tradição que não atualizavam suas matérias. Parece-nos que, a partir do século $\mathrm{XVI}$, as epopeias retomaram a ideia de limite, característica da prudência antiga, superada pelo ímpeto centrífugo das grandes navegações. Pretende-se, neste trabalho, apresentar alguns poemas épicos e, com base na maneira como construíram o éthos/a persona dos heróis, analisar um movimento histórico que propõe a superação do Nec Plus Ultra (não mais além) pelo Plus Ultra (mais além), algo que comparece de forma consistente no universo das epopeias. Palavras-chave: Nec Plus Ultra; Plus Ultra; epopeias.

\section{Abstract}

Until the eighteenth century, the rhetorical and poetic genres were regulated by the notion of imitation, that is, the poets emulated the auctoritas (authorities) to invent their poems. It is an artistic paradigm, based on the conventions and specificity of each discursive genre, among which we will highlight the epic. Although we must consider the long duration of the Rhetorical Institution, we cannot neglect the historical aspects that underpin each poem, that is, it is not because they emulated tradition that they did not update their materials. From the 16th century, it seems that the changes were more drastic, since the idea of limit, characteristic of ancient prudentia, was overcome by the centrifugal impetus of the great navigations. The aim of this paper is to present some epics and, from the way they built the éthos / the persona of heroes, to analyze a historical movement that proposes the overcoming of Nec Plus Ultra (no further) by Plus Ultra (beyond), something that appears in the universe of epics. Keywords: Nec Plus Ultra; Plus Ultra; epics.

\footnotetext{
* Universidade Federal de Uberlândia (UFU), Instituto de História (INHIS), Uberlândia, MG, Brasil. cleber.ufu@gmail.com <https://orcid.org/0000-0002-3930-3936>
} 


\section{O GÊNERO ÉPICO}

Para pintar um retrato de Helena, Zêuxis teria solicitado aos habitantes de Crotona a presença de cinco belas jovens para assimilar o que há de mais sublime em cada uma e, assim, retratar uma personagem digna da autoridade homérica. Esse famoso pintor grego, por outras palavras, pretendia, aproveitando-se dos atributos admiráveis de figuras particulares e empíricas, compor uma persona, uma pessoa detentora de grande beleza. A anedota em questão ajuda-nos a compreender melhor, por exemplo, os heróis épicos que Homero e outros poetas empregaram em seus poemas, detentores de virtudes grandiosas (também baseadas em características particulares) que determinam seu caráter. O humanista Leon Battista Alberti (1404-1472) repetiu a anedota de Estrabão, chegando ao seguinte juízo: "Qualquer que seja a arte que se pratique, deve-se, porém, ter sempre diante dos olhos algum exemplo elegante e singular para observar e retratar" (Lichtenstein, 2004, p. 146). Quando censurou a imitação da natureza enquanto pressuposto da arte, Hegel desferiu um ataque mortal contra os procedimentos genéricos de composição artística, contra a mimese, assim como fez Baudelaire alguns anos depois, ao dizer que a doutrina baseada na imitação era "inimiga da arte", já que a "natureza é feia" e que "os monstros" da fantasia seriam mais dignos de atenção (Lichtenstein, 2004, p. 115).

O primeiro a nos oferecer uma exposição doutrinária a respeito do gênero épico também afirmou que a imitação era um dos fundamentos do fazer artístico: Aristóteles (2017, Poet. 9.1451a) definiu a epopeia retomando as características da tragédia. A princípio, ambos os gêneros se aproximam quanto à opção que fazem pelos objetos de imitação: homens superiores e exemplares, merecedores de glória perene. No entanto, a tragédia é dramática e a matéria que ela privilegia dificilmente ultrapassa o intervalo de um dia. A epopeia, além de dramática, é narrativa, o que lhe confere a possibilidade de investir na variedade e diversidade de episódios, de modo a impedir a monotonia e o tédio de seu auditório. Para Aristóteles, ela deveria recorrer exclusivamente ao verso heroico, denominado hexâmetro datílico, por ser o mais pausado e amplo. A tragédia, por sua vez, poderia utilizar metros variados.

O poeta romano Horácio, alguns séculos depois, afirmou que a epopeia trata de "res gestae regumque, ducumque, et tristia bella", ou seja, de "coisas feitas por reis e chefes e de tristes guerras". A finalidade do gênero épico seria o prazer decorrente da admiração das ações capazes de efetuar o kléos, a fama imorredoura. No século XVI, Júlio César Scalígero, Antonio Minturno e Torquato Tasso, dentre outros, vão glosar Horácio para referir e reforçar a 
importância do gênero, isso porque enquanto durou a instituição retórica, conservou-se o valor do heroísmo, que a poesia elabora como modelo de comportamento. ${ }^{1}$ Diferentemente de Aristóteles, muitos poetas passaram a conceber a epopeia como gênero maior, superior inclusive à tragédia, como é o caso de Torquato Tasso, que definiu epopeia como "imitação de ação ilustre, grande e perfeita, narrada com altíssimo verso" (“imitazione d'azione illustre, grande e perfetta, fatta narrando con altissimo verso"), que pretendia "mover os ânimos com a maravilha e se beneficiar deste expediente" ("muovere gli animi con la maraviglia e di giovare in questa guisa”) (Tasso, 1974, p. 822).

\section{O heroísmo éPico: Gilgámesh, Aquiles, Odisseu}

No decorrer dos séculos XIX e XX arqueólogos investiram recursos e esforços para escavar antigas cidades soterradas do Oriente Médio. Como consequência, acabaram protagonizando descobertas cuja importância não se pode mensurar. Por meio do poema babilônico intitulado Ele que o abismo viu, também conhecido como Epopeia de Gilgámesh, acompanhamos a saga do quinto soberano de Úruk que reinou após o dilúvio. As tabuinhas encontradas levam a supor que o primeiro fragmento dessa jornada remonta ao século XXII a.C., muito tempo antes da redação dos poemas homéricos. A empresa heroica de Gilgámesh, filho de uma deusa e, portanto, dois terços divino e um terço humano, tornou-se objeto de uma longa tradição poética por meio da qual foram-lhe atribuídos feitos de grande importância, como a construção da muralha da cidade de Úruk. A versão mais completa de sua saga foi criada no ápice desse ciclo heroico, atribuída ao sábio Sin-léqi-unnínni (2018) e estabelecida por volta do século XIII a.C.

Em sua busca pela imortalidade, Gilgámesh visitou os confins do mundo para consultar Uta-napíshti e sua esposa, que sobreviveram ao dilúvio graças à construção de uma arca e foram agraciados com a vida eterna. Como consequência dessa longa viagem, o rei de Úruk acessou os segredos ocultos dos deuses e conheceu, de perto, a condição humana, aprendendo que a morte é uma condição insuperável da humanidade. De acordo com Jacyntho Brandão, o melhor equivalente grego do herói mesopotâmico seria Héracles, "que age sozinho em aventuras que não se dão no contexto de guerra alguma”. No entanto, a tomar pelo ciclo homérico, há diferenças dignas de nota:

se Aquiles e Ulisses são guerreiros-heróis, Gilgámesh é herói sem ser guerreiro. Aquiles tem um companheiro, Pátroclo, mas luta tendo em torno de si seu exér- 
cito, bem como o de todos os gregos; Ulisses chega sozinho a Ítaca, terminada a guerra, mas na maior parte de sua viagem conta com os companheiros de navegação. São exemplos de sagas coletivas, em que inclusive outros heróis se sobressaem, como Diomedes e Heitor, ao passo que Gilgámesh é um herói solitário, o próprio mote de Ele que o abismo viu sendo sua solidão, quebrada brevemente com a criação, pelos deuses, de um par para si, Enkídu, mas logo reimposta a ele com a morte do amigo, sendo essa solidão o que motiva sua busca pela imortalidade e leva ao desfecho sobre a impossibilidade de conquistá-la. (Brandão, 2018)

Peter Jones, por sua vez, não deixa de destacar algumas proximidades: "tanto Aquiles como Gilgámesh são filhos de deusas; ambos perdem um amigo querido; ambos ficam arrasados com essa perda e adotam uma ação extrema na tentativa de compensá-la" (Jones, 2013, p. 23). Para compreender melhor os paralelos em questão, convém investigar de perto o éthos dos dois heróis homéricos escalados como protagonistas de seus poemas.

Se a Ilíada (Homero, 2002) retrata a trajetória de um jovem herói que partiu de casa para a guerra, conquistando glória (kléos) perene em contrapartida à perda do regresso (nóstos), a Odisseia (Homero, s. d.) canta um homem maduro que da guerra retornou ao lar, não sem enfrentar várias peripécias. Um poema aborda o antes, quando Troia permanecia intacta e Aquiles com vida; o outro deteve-se no depois, relatando a memória e encenando o luto. Com seus 15.693 versos hexâmetros, a Ilíada tem por objeto a cólera de Aquiles, que causou aos gregos (também identificados como aqueus, argivos ou dânaos) inúmeras penas. A Odisseia, por sua vez, com um total de 12.109 versos, narra a viagem a contragosto de Odisseu e as peripécias que precisou enfrentar para retornar a Ítaca.

Os heróis retratados nos poemas homéricos, ainda que situados em circunstâncias muito recuadas, em determinados momentos parecem especialmente próximos do nosso presente. Talvez porque experimentam constantemente a dor da separação, o receio de morrer ou a alegria do reencontro, situações características da condição humana. Essa ponte entre dois tempos históricos torna-se ainda mais nítida quando deparamos com as descrições econômicas das personagens, quem sabe para deixar a cargo do leitor a ação de apreendê-los a partir de seus próprios valores. Seja como for, esse herói épico destaca-se frente aos homens porque conta com características excepcionais (força, astúcia, capacidade de comando etc.). No entanto, eles não alcançam a condição divina, pois continuam mortais. Trata-se de uma "impotência heroica": são homens nobres capazes de conquistar fama, mas não escapam à 
morte, ao sofrimento, à privação. No final das contas, todos os homens estão fadados a um destino, ao arbítrio das Moiras, aos desígnios de Zeus.

É possível encontrar, nos casos mesopotâmico e grego, figurações da condição humana. Por intermédio das Musas, Homero não apenas inventou tipos como Aquiles e Odisseu, mas também versou sobre a fragilidade humana. A preservação do feito ilustre só seria possível por intermédio do canto inspirado, que anuncia a memória e celebra o kléos, a fama imorredoura. Na proposição/ invocação da Ilíada, depois de pedir o auxílio da Musa, o aedo introduziu o embate entre Aquiles, filho de Peleu, e Agamêmnon, "rei dos homens", que "aos Aqueus tantas penas / trouxe, e incontáveis almas arrojou ao Hades / de valentes, de heróis, espólio para cães, / pasto de aves rapaces” (Homero, 2002, Il. I, 2-5). Algo parecido ocorreu nas liminares da Odisseia, quando Homero mencionou as dores que Odisseu padeceu quando de seu retorno, "empenhado em salvar a vida e garantir o regresso dos companheiros" (Homero, s. d., Od. I, 2-5). Em Ele que o abismo viu, o teor ruinoso foi mencionado na metade do poema, quando Enkídu estava prestes a padecer e, especialmente, na ocasião em que Gilgámesh lamentava a perda do amigo. Isso porque o texto não foi escrito in media res, como era comum à epopeia grega. Aliás, ele também não cumpriu outro requisito, já previsto na Poética de Aristóteles: a adoção do hexâmetro datílico, algo inventado muitos séculos depois.

Por fim, poder-se-ia retomar a narrativa situada ao final da tabuinha 2, quando, numa assembleia organizada em Úruk que antecedeu a partida do herói rumo à Floresta de Cedros, seu companheiro e conselheiros recomendaram a desistência da missão, indicando os perigos que espreitavam nesse limite, protegido por um guardião "muito grande": "sua voz é o dilúvio! / Sua fala é fogo, seu alento é morte" / Ele ouve a sessenta léguas um murmúrio da floresta" (2, 221-223). Várias acusações então foram feitas: "És jovem, Gilgámesh, teu coração te impulsiona, / Isso que julgas não conheces.” (2, 289-290); "Não confies, Gilgámesh, em toda tua força! / Teus olhos se fartem, no ataque confia!" (3, 2-3). A floresta parece figurar algo como as colunas de Hércules, um limite que não convinha ultrapassar. Talvez a morte do amigo seja uma punição também à sua hýbris, amplificada com as palavras rudes dirigidas a Ishtar. Assim, Humbaba representaria uma espécie de Polifemo, seja pela falta de hospitalidade, seja pelo fato de não comer pão e viver apartado da cidade. A analogia, no entanto, é limitada, já que Odisseu caiu nas garras de Polifemo a contragosto, e Gilgámesh buscou Humbaba por livre iniciativa, o que não o impediu de tremer perante o desafio: "O medo cai sobre Gilgámesh: / Um torpor toma seus braços / E debilidade cai-lhe sobre os joelhos” (5, 28-30). 
$\mathrm{O}$ ato de recuar ao poema Ele que o abismo viu não deve ser considerado como uma tentativa de buscar a pré-história da epopeia, o que seria improdutivo, mas pode-se encontrar ali, nessas práticas letradas redescobertas há pouco, artefatos capazes de nos tornar mais próximos dos códigos de sua composição.

\section{Eneias e a persona de Augusto}

Virgílio escreveu "a” epopeia de Roma, mas não foi o primeiro romano a escrever epopeia. Pode-se dizer que a épica latina atingiu seu auge sob o principado de Otávio Augusto, mas tem-se notícia de alguns poemas anteriores, como é o caso da tradução da Odisseia realizada por Lívio Andrônico no século III a.C. De sua obra restam-nos pouquíssimos fragmentos, o que dificulta a formulação de qualquer juízo. Diferentemente de Homero, Andrônico recorreu ao verso satúrnio, procedimento repetido por Névio algumas décadas depois, quando escreveu Bellum Poenicum, poema sobre a primeira guerra entre Roma e Cartago ocorrida entre os anos de 264 e 241 a.C. Essa epopeia também alcançou nosso século de forma bastante fragmentada, o que se repete com os Annales, de Quinto Ênio (239-169 a.C.). Dos seus 18 cantos, restam-nos cerca de 600 versos. Assim como Névio, ele retratou a trajetória de Eneias e sua chegada ao Lácio, mas foi além, incorporando episódios posteriores. Ao contrário de seus predecessores e à maneira de Homero, Ênio empregou o hexâmetro datílico, consagrando-o como metro épico por excelência. Epopeias posteriores, como a Eneida de Virgílio e a Farsália de Lucano recorreram ao mesmo metro (Vasconcellos, 2014).

Quando Virgílio elaborou seu poema épico à época da pax romana instituída por Otávio Augusto, imperador que o poeta (como outros antes dele) associou à gens Iulia iniciada no tempo mítico de Eneias, a experiência da catábase não parecia inverossímil aos leitores, porque o mundo de Hades era possível. Assim, quando Anquises mostrou ao filho, no canto sexto da Eneida, sua descendência (por meio da metempsicose) demorando-se na figura de Augusto, o leitor pôde contemplar a majestade de seu presente sendo projetada no tempo heroico da guerra de Troia com ares proféticos. Embora haja uma evidente analogia entre as experiências de Ulisses e Eneias, Homero e Virgílio retrataram o mundo de Hades com propósitos particulares, datados. A emulação (aemulatio) é justamente isto: uma imitação com vistas à superação do modelo. 
O poema, portanto, apresenta a justificação mítica da vocação dos Iulli, como lembra Pierre Grimal (2008, p. 73). Retoma-se uma famosa passagem da Ilíada na qual se efetua uma promessa dos deuses para Eneias. Após a destruição de Troia e o fim da descendência de Príamo, o poder retornaria a Eneias e a seus descendentes, que obteriam o império do mundo. Virgílio não inventa a lenda. Independentemente disso, a matéria do poema religa a Roma imperial ao passado longínquo e prestigioso do mundo helênico. Os romanos não faziam, portanto, outra coisa senão cumprir um destino já referido pelos deuses no passado. Se a nós, homens do século XXI, esse roteiro mítico aparenta fábula poética inventada para entreter, no tempo em que circularam as versões manuscritas da epopeia não se fazia diferenciação consistente entre História e Mito. Não se duvidava da existência de Aquiles e de outros heróis da Antiguidade. Mais do que isso, a epopeia trazia consigo uma lição de história, afinal, a narrativa dos acontecimentos legitima o império e as ações de Augusto, que viria a tornar as profecias de Júpiter verdadeiras.

Em termos bastante sintéticos, a jornada de Eneias busca efetuar o destino, o fatum, o desígnio dos deuses, que esperavam dele a fundação de uma nova Troia. Chegando à região do Lácio por interferência de divindades, fez inimigos e buscou aliados. Os conflitos resultaram num desfecho muito controverso: por que razão Eneias assassina o oponente, mesmo depois de rendido? Ao que parece, esse episódio mantém analogias com o confronto entre Otaviano e Marco Antônio. Quando Eneias, dominado pelo furor, mata Turno, o leitor pode vir a pensar em Otaviano quando, podendo perdoar Marco Antônio e exercer a sua tão afamada clemência, acabou por condená-lo ao suicídio. Turno chega mesmo a suplicar ao oponente: ulterius ne tende odiis (não leves mais longe o ódio). Teria o herói abandonado a virtude que o caracteriza, ou seja, a pietas? Convém recordar que Eneias firmara um pacto com Evandro, seu anfitrião e aliado. Este lhe havia concedido um exército e os serviços do próprio filho, Palante, morto em combate pela destra de Turno. O troiano, ao visualizar o cinturão de Palante, espólio de Turno, "arde em fúrias, e a ira o faz terrível". O termo latino pietas, que caracteriza Eneias, não corresponde à piedade em sua conotação cristã. Trata-se de uma obediência aos deuses e aos superiores. O adjetivo pius, proveniente de pietas, comumente traduzido, no medievo, como santo, é muito recorrente na Eneida, e designa "o estrito cumprimento dos deveres para com os deuses, a família e o Estado, cumprindo a vontade de Júpiter, em consonância com o destino". Aristóteles, em sua Retórica, afirma que a piedade consiste numa certa pena causada pela aparição de um mal destruidor e aflitivo que afeta quem não merece ser 
afetado. Apesar de ter relações com a pietas romana, esse conceito transcende tal significado. Logo, poupar Turno envolveria quebrar um pacto entre amigos, entre iguais. ${ }^{2}$

\section{EPOPEIA HAgIOGRÁFICA}

Um novo paradigma de comportamento se instituiu com a invenção de um Deus transcendental responsável pela fabricação ex nihilo do mundo. Javé, criador de tudo, estabeleceu com Israel uma aliança, um pacto de fidelidade que foi quebrado em vários momentos. Esses rompimentos podem ser pensados como vetores que orientam a trama presente no Antigo Testamento. Depois da criação, desaprovando moralmente o desempenho humano, Javé promoveu o dilúvio, fulminando a humanidade: no entanto, assegurou a sobrevivência de Noé. É dessa linhagem que surgiria Abraão, o primeiro dos grandes patriarcas, que Javé foi buscar na cidade de Ur, na Mesopotâmia. Desde que foi investido com a missão de fundar um povo, ele se comportou "como perfeito fiel e devoto de Javé, e apenas Dele: como perfeito monoteísta" (Bottéro, 2011, p. 242). Sua obediência foi irrestrita a ponto de se dispor a sacrificar o filho, Isaac. Outro protótipo de herói, grande protagonista da narrativa do Exxodo, foi Moisés, que libertou Israel da opressão egípcia e empreendeu uma missão duradoura e verdadeiramente épica.

A ideia de sacrifício, recorrente no Antigo Testamento, adquiriu novos contornos nos Evangelhos, quando Jesus, filho de Deus, morreu para redimir a humanidade, livrando-a da mácula do pecado original. Os apóstolos, cientes do projeto de Deus para o mundo, deveriam difundir e agir em conformidade com os mandamentos, com as regras universais anotadas na Sagrada Escritura. O monoteísmo judaico-cristão, como se sabe, fundamenta-se num princípio teleológico que culminará no juízo final. O homem deveria, portanto, se comportar ciente de que possui o livre-arbítrio: logo, o mal seria consequência de uma escolha ruim, como aquela feita por Lúcifer quando se rebelou contra o Criador, ou a de Eva, quando cedeu à tentação, ou ainda a de Caim, precursor do fratricídio.

Alguns poetas da Antiguidade tardia recorreram às narrativas bíblicas, especialmente às experiências de martírio, para compor epopeias. Arátor, por exemplo, escreveu sua História apostólica na primeira metade do século VI de nossa era, adotando cerca de 2.300 versos heroicos para exaltar a gesta evangelizadora dos apóstolos Pedro e Paulo, dedicando o poema ao papa Virgílio. O próprio poeta admitiu que efetuou uma versificação dos Atos dos apóstolos, 
seguindo de perto o texto de Lucas, mas filtrando-o pelo crivo épico. Sendo assim, na companhia de poetas como Prudêncio, Sedúlio e Juvenco, Arátor recorreu a um subgênero que poderia ser identificado como "epopeia bíblica". No entanto, o poema não se restringe à paródia do texto bíblico, pois nele é possível constatar, por exemplo, a imitação de poetas "pagãos" como Virgílio e Lucano. Além disso, Arátor intervém na narrativa, de modo a não somente destacar as características dos heróis, mas também expor e esclarecer matérias teológicas controversas do seu tempo. Como afirmou José Manso, ele “aprendera com Virgílio como uma epopeia, cuja ação remonta a tempos muito anteriores ao seu, pode enaltecer e legitimar feitos e personagens do presente" (Manso, 2012, p. 96). Por fim, convém lembrar, ainda com Manso, que há nos versos de Arátor elementos antissemitas, que são percebidos, por exemplo, na maneira como o poeta omite quase todas as informações sobre os patriarcas e, portanto, sobre o passado de Israel, ou em outros momentos nos quais ele vitupera o povo judeu, adotando expressões como "Israel coxo", "raça perversa", "Judeia mais cruel do que a serpente" etc., ou ainda quando associa a Paulo um papel extremamente duro e intolerante para com o povo judeu, algo que não encontra paralelos com a narrativa bíblica (Manso, 2012, p. 105). Vale recordar que o poema em questão foi, no ano de 1513, utilizado pelo português Aires Barbosa em suas aulas de gramática em Salamanca, publicando seus comentários à obra alguns anos depois.

Poesia épica hagiográfica seria um desdobramento da poesia hagiográfica neolatina, da qual seria exemplo o Iesueide (1445), do médico de Pádua Girolamo della Valli, que, imitando Virgílio, narrou a vida de Jesus, sobretudo em sua dimensão humana. Há também outras poesias escritas à época dedicadas a temas bíblicos, como Christiados (1535), de Jerónimo Vida, e De Partu Virginis (1521), de Jacopo Sannazaro (Urbano, 2005, p. 388-389). Esses poemas foram bastante populares nos meios escolares, especialmente na Companhia de Jesus. Carlota Urbano notou um aumento considerável de poemas épicos hagiográficos a partir do final do século XVI, uma vez que a piedade cristã pós-tridentina confirmou e estimulou o apreço dos poetas peninsulares pelo tema hagiográfico. Personagens como são Vicente, são Francisco Xavier e santo Inácio de Loyola foram lembrados nesse período.

\section{O MODELO CAMONIANO}

O heroísmo, no contexto português dos séculos XVI-XVIII, baseava-se no reto uso do livre-arbítrio e no cumprimento de um pacto político 
legitimador da hierarquia e da autoridade soberana do rei. Os poemas épicos escritos nesse período encenaram ações heroicas particulares, historicamente articuladas com o intuito de instruir, comover e deleitar seus leitores. A empreitada missionária para efetuação da catequese e a necessidade de se legitimar a expansão marítima, dentre outras coisas, contribuíram com a efervescência de epopeias na Península Ibérica.

Camões, aristocrata pertencente a uma família galega da pequena nobreza que se instalou em Portugal no século XIV, durante o reinado de Fernando I, publicou sua epopeia em 1572. Ele foi "fidalgo pobre", lembra-nos Hansen, tipo letrado orgulhoso da nobreza e com dificuldades de conceber a riqueza como critério definidor da hierarquia. Não apreciava o comércio ou o trabalho manual, mas valorizava a carreira das armas (Hansen, 2005, p. 169). Embora seu poema se detenha nos feitos notórios de Vasco da Gama, o alvo de seu canto é plural, pois a narrativa se ocupa de circunstâncias das quais o herói não participou. Há pelo menos três histórias justapostas n'Os lusíadas: a empresa de Gama, a história dos reis e guerreiros das dinastias de Borgonha e de Avis, e os deuses gregos e latinos que abundam a obra. Destinada a d. Sebastião, rei de Portugal, a obra retrata a empresa colonizadora, com ênfase nas aventuras que permitiram aos portugueses divisar rotas de acesso às Índias. Valendo-se da máquina mitológica, o poeta estilizou a narrativa tornando-a atrativa e, sob o véu de um aparato alegórico, ele censurou, exortou e elogiou as atitudes e inclinações das personagens, deixando clara uma postura favorável aos princípios reinóis e, especialmente, à ética cristã, definindo, assim, um éthos ou modelo de conduta a ser divulgado como padrão de comportamento.

Nem todos aplaudiram o título que Camões escolheu para sua epopeia, por não seguir de perto as escolhas de Homero e Virgílio, que utilizam o título para aludir ora ao nome do herói/protagonista (é o caso da Odisseia e da Eneida) ora ao cenário em que se deflagra o conflito bélico (como ocorre na Ilíada). ${ }^{3}$ De acordo com o helenista Jean-Pierre Vernant, o herói cantado na épica greco-latina "é ao mesmo tempo o representante das expectativas coletivas, o responsável pela salvação comum e um indivíduo que coloca suas façanhas pessoais acima de tudo" (Vernant, 2002, p. 384). Dessa forma, nomear o protagonista no título da obra indica que suas façanhas individuais favoreceram a sobrevida da coletividade de que faz parte. Quando Camões inventou seu título, salientou a importância da harmonia e da concórdia estabelecida entre os habitantes do reino que, em uníssono, deveriam assegurar a unidade do Império. A tomar, então, pelo caráter "corporativista" da política portuguesa, é possível inferir que a referência a heróis, no plural, poderia favorecer a 
recepção por parte dos leitores, que deveriam cogitar a possibilidade de conquistar reconhecimento e fama, caso suas ações se ajustassem em alguma medida às condutas heroicas retratadas no poema. Não é de estranhar, portanto, que o poeta tenha optado pelo título Os lusíadas, dispensando o singular Vasco da Gama. O louvor épico salienta a necessidade de harmonia do organismo social, independentemente do local ou do(s) herói(s) que a conduzem. A poesia cristã canta a coesão do corpo místico e, concomitantemente, o respeito às hierarquias.

A proposição d'Os lusíadas evidencia a matéria poética e indica o preceito artístico da imitação logo no seu primeiro verso: "As armas e os barões assinalados”. No caso, o poeta mencionou, por sinédoque, as façanhas militares, matéria privilegiada da épica. Esse trecho recupera um estilo alto e sublime, pois emula o primeiro verso da Eneida: "Eu canto as armas e o barão". Torquato Tasso, em sua Jerusalém Libertada, recorre ao mesmo verso para principiar seu poema: "Canto l'arme pietose e 'l capitano" (Tasso, 1998, p. 113). No entanto, Camões não reduz seu louvor a um herói apenas, mas a um conjunto de barões que não identifica de imediato, o que justifica o uso da terceira pessoa do plural. Mais adiante, Camões salienta o caráter inédito das façanhas que vai cantar, pois os navegantes singraram mares nunca dantes navegados, ultrapassando a ilha de Ceilão (também conhecida como Taprobana, atual Sri Lanka). O poeta adianta para o leitor que as ações que vai narrar terminam com a edificação de um "Novo Reino", à maneira de Virgílio que, em seu exórdio, antecipa que a razão última da trajetória de Eneias é a fundação de Roma.

É preciso levar em consideração que o tempo, no século XVI, é considerado criação de Deus. Sendo assim, todas as ações de Vasco da Gama incluem, necessariamente, a presença de Deus, que se repete em todas as diferenças históricas. Não há punição que não Lhe diga respeito, não há acontecimento no qual Ele não esteja presente. Há, porém, limitação humana, pois o homem não entende com clareza os sentidos da justiça divina. Se todos os momentos históricos são análogos, justamente por implicarem a identidade de Deus, deduz-se que a história pode ensinar maneiras de agir conformadas à vontade da Providência.

António José Saraiva atribuiu às personagens d'Os lusíadas falta de vida e ânimo, supondo a inexistência do heroísmo entre elas. O autor desconfia que o foco da narrativa sejam as deidades mitológicas, e não Vasco da Gama e seus pares. Muitas vezes as personagens mitológicas, sob o efeito de prosopopeia, são consideradas aquelas que realmente agem no decorrer das narrativas épicas. Saraiva afirma que os deuses não são "simples retórica, mas as figuras com 
que se ata e desata a própria fábula do poema" e considera que "n’Os lusíadas não há outras personagens vivas senão os deuses", o que delega aos heróis um papel de meros coadjuvantes, que "limitam-se a presenciar, a esperar e a agradecer". Se entendermos na mitologia uma função alegórica, que muitas vezes dá a entender a presença dos desígnios da providência, a afirmação de Saraiva se justifica. Contudo, o herói não apenas presencia, espera e agradece como também lê, nas entrelinhas, a matéria providencial, e age como instrumento de Deus, para a materialização de suas vontades (Saraiva, 1980, p. 158-166). O heroísmo figurado nas epopeias católicas do século XVI reafirma a perspectiva católica contrarreformada, pois os poetas emularam a filosofia aristotélico-tomista, edificando uma conduta afinada à reta razão, à moderação dos afetos, de modo que não há neles o ímpeto guerreiro de um Aquiles, mas a humildade própria de um agente da Providência que, simultaneamente, atua como braço da realeza. Se negligenciarmos, portanto, a concepção providencialista da história portuguesa, não teremos condições de compreender o protagonismo assumido por nobres como Vasco da Gama.

\section{UMA DISCUSSÃO SOBRE O LIMITE}

Em um texto voltado para a arte renascentista, Luiz Marques (2017) propõe o século XVI como momento no qual houve a superação do Nec Plus Ultra (não mais além) pelo Plus Ultra (mais além). As categorias em questão remetem a outras duas, que o autor vai utilizar posteriormente: forças centrípetas e centrífugas. Estas são as duas balizas de suas reflexões, que referem diferentes tempos e lugares para dar conta de uma análise mais ampla sobre o "limite". Em termos gerais, o autor sugeriu que, até o século XVI, havia um comedimento e uma tendência, ao menos no mundo ocidental, de respeitar certos limites compreendidos como intransponíveis, pois ultrapassá-los significaria incorrer em hýbris, em excesso passível de punição. Esses limites eram físicos, mas também éticos. Foi a partir da expansão marítima, no entanto, que essa lógica foi subvertida, de modo que ultrapassar esses mesmos limites configuraria uma ação virtuosa digna de encômios. O capitalismo, no século XIX, seria resultado ou sintoma dessa nova maneira de se conceber o limite e as fronteiras (naturais e éticas). A compreensão das epopeias gregas e romanas, de um lado, e das epopeias portuguesas, de outro, pode ser aprimorada trabalhando-se com essas categorias.

Na Ilíada, o avanço das frotas marítimas gregas rumo a Troia não condizia com uma iniciativa expansionista, mas com uma compensação centrípeta: a 
necessidade de restaurar a ordem transgredida por Páris. O mesmo acontece na Odisseia, epopeia da viagem, mas uma viagem de retorno à pátria. A prudência seria determinada pelo ímpeto centrípeto da sabedoria, e não pela iniciativa exploratória e transgressora. Deslocar-se para fora equivaleria, portanto, à perda da Idade de Ouro, que Ovídio caracteriza como momento no qual o pinheiro ainda não "descera para as líquidas ondas e nenhum mortal conhecera outras praias além das suas” (Marques, 2017, p. 35). Mesmo a viagem de Eneias não é centrífuga, mas uma tentativa de revivescência de Troia no Lácio, assegurada pela translatio em terra latina dos "penates pátrios", deuses tutelares de Troia. Embora elabore o mito do futuro de Roma, este "podia ter força de mito tão somente porque se fundava num mito de origem" (Marques, 2017, p. 35).

De acordo com Luiz Marques, esse limite espacial ocidental no mundo antigo foi estabelecido pelas colunas que Hércules havia erigido sobre os rochedos de Gibraltar, informação que encontramos na Geographia, de Estrabão, mas também em De situ orbis, de Pompônio Mela. Vários outros povos, segundo Heródoto, ultrapassavam esses limites, que eram gregos, não apenas no sentido geográfico, mas também no filosófico e moral, pois transgrediam uma sabedoria prática que consistia no autoconhecimento e em viver dentro dos limites da razão e da natureza" (Marques, 2017, p. 37). Trata-se, portanto, do nec plus ultra.

Luigi Marliano forjou para o futuro Carlos V, no ano de 1516, uma empresa na qual constavam a inscrição Plus Ultra (mais além) e a imagem das colunas de Hércules. Possivelmente ela "traduzia a ideia geral e abstrata de uma nova concepção de virtù, a qual consistia, doravante, no predomínio do ímpeto sobre a autocontenção, predomínio que desafiava, recusava e se contrapunha abertamente à tradição da sophrosyne, da phronesis e da prudentia" (Marques, 2017, p. 42). A combinação entre as colunas e a expressão "mais além" poderia reforçar o ímpeto imperial, centrífugo, legitimado pela ambição de universalizar o cristianismo. No caso do rei português Manuel I, deparamos com um emblema no qual se encontra retratada a esfera armilar, instrumento astronômico de origem obscura. A esfera, no caso, seguiu acompanhada da inscrição In Te, Domine, Spes Mea (Em ti, Senhor, a minha esperança). Sua importância cultural perdurou nos séculos posteriores a ponto de, em 1911, integrar a bandeira nacional de Portugal. Esse objeto, à época do rei Venturoso, poderia indicar, por sinédoque, o projeto lusitano de cartografar o mundo. Não por acaso, a expansão imperial e a conversão dos infiéis constituíam as forças motrizes da empresa encabeçada por Vasco da Gama, que foram sublimadas pela 
poesia engenhosa do século XVI, tornando-se matéria privilegiada das epopeias.

A épica camoniana, segundo Luiz Marques, "não evoca a reparação de uma transgressão como a de Páris, o retorno a casa como o de Ulisses ou um mito de origem como a fundação de Roma. O que o poema canta é, de fato, a superação da Antiguidade" (Marques, 2017, p. 43). Em Camões, duas personagens figuram as forças centrípetas: o velho do Restelo e o Gigante Adamastor. O primeiro fala aos nautas portugueses, antes da partida, que as viagens movidas pela cobiça e o deslocamento para longe da terra pátria seriam dignas de censura. Já o Adamastor, personificação do Cabo das Tormentas, simboliza as colunas de Hércules na medida em que se encontra ali para impedir que aventureiros alcançassem os "vedados términos". ${ }^{4}$ Essas figuras representam a prudentia antiga, o autocontrole e o comedimento, que podem ser encontrados na seguinte passagem da epopeia de Lucano, proferida por um dos navegantes:

Olha o que o pélago furioso nos apronta:

Não se sabe se Zéfiros sopram, ou Austros.

Indeciso o mar fere em toda parte a nau.

Pelas nuvens é o céu de Noto. Ao som das águas

Se atentarmos, o Coro é que vem. Com tal mar,

Nem naufrágio, nem nau, a Hespéria tocará.

Desistir e evitar a rota intransitável,

Eis a saída. Que eu a nau batida possa

Logo levar a terra antes que seja tarde.

(Lucano, 2011, V, 568-576)

A prudência antiga também pode ser detectada na sabedoria que Sêneca felicita na atitude de Lucílio, em sua segunda epístola: "não corras o mundo nem te inquietes com mudanças de lugar. Tal agitação é própria de um ânimo enfermo. A primeira prova de uma mente bem composta é, a meu ver, poder conter-se e residir em si" (Sêneca, 1985, p. 5). Inquietude que Horácio referiu em uma de suas odes: "Feliz aquele que, longe dos negócios, / como a antiga raça de mortais, / faz trabalhar seus bois nos campos paternos, / livre de toda usura, / e não o acorda, qual a um soldado, a cruel trombeta, / nem teme o mar bravio, / e evita o fórum e os soberbos limiares / dos poderosos" (Fonseca, 1967, p. 80). A terceira oitava d'Os lusíadas assinalou outra forma de encarar as navegações: 
Cessem do sábio Grego e do Troiano As navegações grandes que fizeram; Cale-se de Alexandro e de Trajano A fama das vitórias que tiveram; Que eu canto o peito ilustre Lusitano, A quem Netuno e Marte obedeceram. Cesse tudo o que a Musa antiga canta, Que outro valor mais alto se levanta.

(Camões, 2005, I, 3).

Ao finalizar sua proposição, Camões justapôs duas memórias para julgar qual delas é a mais digna de canto e louvor, mandando cessar as navegações e os feitos de Ulisses e do troiano Eneias, bem como a fama de Alexandre o Grande, e do imperador romano Trajano. Para reforçar a superioridade portuguesa, o poeta retoma a relação hierárquica estabelecida entre homens e deuses pagãos: se, como versa o poeta antigo, os homens (mortais) deviam respeito às deidades (imortais), laço que constitui a axiologia épica em Homero, para os portugueses essa hierarquia se esvazia, o que indica depreciação do modelo politeísta e amplificação do lugar que se confere à religião cristã. Quando o poeta afirma que Netuno - deus romano dos mares - e Marte - deus romano da guerra - obedeceram aos nautas portugueses, ele não apenas subverte as hierarquias pagãs como também amplifica as habilidades dos lusitanos, atribuindo-lhes perícia nas artes da navegação e nos artifícios bélicos.

A exploração do Atlântico, efetuada e aperfeiçoada ao longo do século XV pelas Coroas ibéricas, seguiu acompanhada de um desenvolvimento das embarcações, pois notou-se a insuficiência das práticas náuticas empreendidas no Mediterrâneo. Os portugueses, como se sabe, encontraram e ocuparam, nas primeiras décadas do Quatrocentos, as ilhas Canárias, os Açores (inaugurando a famosa "volta da Guiné) e Cabo Verde. Em 1434, Gil Eanes ultrapassou o cabo Bojador a bordo de uma barca que não superava 30 tonéis, apta para pesca ou para navegação fluvial e de cabotagem. Em 1487 foi a vez de Bartolomeu Dias vencer o Cabo da Boa Esperança, a princípio conhecido como Cabo das Tormentas, a bordo de uma caravela de 50 tonéis. A caravela latina mostrou-se a mais apta em explorações marítimas mais demoradas, mas a ampliação de seu porte seria fundamental para a navegação interoceânica que ocorreria na sequência. A armada de Vasco da Gama, por exemplo, dispunha de embarcações que não ultrapassavam 120 tonéis. Já Cabral capitaneou naus que alcançaram 300 tonéis. $^{5}$ 
A despeito das palavras do velho do Restelo, que fazem repercutir a contenção antiga, Gama ultrapassou o cabo, deixando de lado suas advertências e ameaças. Como braço da Providência, sua viagem simboliza não apenas a ampliação do Império português, mas a transmissão da palavra divina. Por outras palavras, ultrapassar os limites antigos para converter infiéis, incentivar o comércio e intensificar o exercício missionário alicerçavam os propósitos lusitanos. Plus ultra (ir além) deixa de ser um excesso para tornar-se virtude e, portanto, uma nova forma de prudência. Últimos baluartes do autocontrole antigo, o velho sábio e o promontório foram suplantados pelo primeiro a avançar por mares nunca dantes navegados: no confronto entre antigos e modernos, decreta-se a vitória dos últimos.

\section{REFERÊNCIAS}

ARISTÓTELES. Poética. Tradução, introdução e notas: Paulo Pinheiro. São Paulo: Ed. 34, 2017.

BOTTÉRO, Jean. No começo eram os deuses. Rio de Janeiro: Civilização Brasileira, 2011.

BRANDÃO, Jacyntho L. Introdução. In: SIN-LÉQI-UNNÍNNI. Ele que o abismo viu: epopeia de Gilgamesh. Tradução do acádio, introdução e comentários: Jacyntho Lins Brandão. Belo Horizonte: Autêntica, 2018.

BRAUND, S. Morton. Latin Literature. London: Classical Foundations, 2002.

CAMÕES, Luís de. Os Lusíadas. Edição antológica, comentada e comparada com Ilíada, Odisséia e Eneida por Hennio Morgan Birchal. São Paulo: Landy, 2005.

DOMINGUES, Francisco Contente. Arte e técnica nas navegações portuguesas: das primeiras viagens à armada de Cabral. In: NOVAES, Adauto. A descoberta do homem e do mundo. São Paulo: Companhia das Letras, 1998. p. 209-227.

FELIPE, Cleber Vinicius do A. Heroísmo na singradura dos mares: histórias de naufrágios e epopeias nas conquistas ultramarinas portuguesas. Jundiaí, SP: Paco, 2018.

FONSECA, Carlos Alberto L. Horácio em 'A vida de Soares de Passos'. Humanitas, Coimbra: Instituto de Letras da Universidade de Coimbra, v. 19-20, p. 73-85, 1967. GRIMAL, Pierre. O Século de Augusto. São Paulo: Ed. 70, 2008.

HANSEN, João Adolfo. Introdução: Notas sobre o gênero épico. In: TEIXEIRA, Ivan (org.). Épicos: Prosopopeia / O Uraguai / Caramuru / Vila Rica / A Confederação dos Tamoios / I-Juca Pirama. São Paulo: Edusp, 2008.

HANSEN, João Adolfo. A máquina do mundo. In: NOVAES, Adauto (org.). Poetas que pensaram o mundo. São Paulo: Companhia das Letras, 2005. 
HOMERO. Ilíada (em versos). Tradução: Carlos Alberto Nunes. Rio de Janeiro: Ediouro, 2002.

HOMERO. Odisséia. Tradução: Carlos Alberto Nunes. Rio de Janeiro: Edições de Ouro, s. d.

JONES, Peter. Introdução. In: HOMERO. Ilíada. Tradução e prefácio: Frederico Lourenço. São Paulo: Penguin Classics: Companhia das Letras, 2013.

LICHTENSTEIN, Jacqueline. A pintura - v. 5. Textos Essenciais: da Imitação à Expressão. São Paulo: Ed. 34, 2004.

LUCANO. Farsália. Tradução: Brunno V. G. Vieira. Campinas, SP: Ed. Unicamp, 2011.

MANSO, José Henrique. A epopeia bíblica de Arátor: entre a imitatio e a inventio. Ubiletras, Covilhã, n. 3, p. 89-105, 2012.

MARQUES, Luiz. Vasari e a Superação da Antiguidade: Do Nec Plus Ultra ao Plus Ultra. In: RAGAZZI, A. et al. (org.). Interdisciplinaridade sobre o Renascimento Italiano. São Paulo: Ed. Unifesp, 2017.

SARAIVA, António José. Luís de Camões: estudo e antologia. Lisboa: Bertrand, 1980.

SIN-LÉQI-UNNÍNNI. Ele que o abismo viu: epopeia de Gilgamesh. Tradução do acádio, introdução e comentários: Jacyntho Lins Brandão. Belo Horizonte: Autêntica, 2018.

TASSO, Torquato. Discorsi dell'Arte Poetica ed in Particolare Sopra il Poema Eroico. Milano: Mursia, 1974.

TASSO, Torquato. Jerusalém Libertada. Tradução: José Ramos Coelho. Organização, introdução e notas: Marco Lucchesi. Rio de Janeiro: Topbooks, 1998.

URBANO, Carlota M. Epopeia novilatina e hagiografia: alguns exemplos em Portugal. Humanitas, Coimbra: Instituto de Letras da Universidade de Coimbra, v. 57, p. 383-402, 2005.

VASCONCELLOS, Paulo Sérgio de. Épica I: Ênio e Virgílio. Campinas, SP: Ed. Unicamp, 2014.

VERNANT, Jean-Pierre. Entre mito e política. São Paulo: Edusp, 2002.

VERNEY, Luís António. Verdadeiro método de estudar (Cartas sobre Retórica e Poética). Lisboa: Ed. Presença, 1991.

\section{NOTAS}

${ }^{1}$ Para uma introdução mais completa ao gênero épico, ver: HANSEN, 2008.

${ }^{2}$ Esta é uma dentre as várias interpretações possíveis dessa passagem. Sobre o assunto, ver: BRAUND, 2002.

${ }^{3}$ Nas palavras de Luís António Verney (1713-1792), Camões, apesar do "engenho poético" e da "imaginação fecunda", investiu na criação de uma obra defeituosa, devido à falta de erudição, de juízo e de discernimento. Verney criticou a opção pelo título ao afirmar que 
"os mestres da arte tomam o título, ou da pessoa, como Odisseia, Eneida, ou do lugar de acção, como Ilíada”. O poeta português, “em vez de tomar o dito título de Vasco da Gama etc., toma-o de todos os portugueses, buscando para isto um termo latino que tanto calça aos portugueses navegantes, como aos que ficaram no reino". Ver: VERNEY, 1991, p. 16.

${ }^{4}$ Sobre o papel desempenhado pelo velho do Restelo e pelo gigante Adamastor, ver: FELIPE, 2018.

${ }^{5}$ Sobre as artes e técnicas de navegação portuguesas, ver: DOMINGUES, 1998.

Artigo recebido em 19 de outubro de 2019.

Aprovado em 13 de janeiro de 2020.

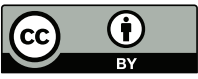

